\title{
WYKAZ REFERATÓW WYGLOSZONYCH NA KRAJOWYCH I ZAGRANICZNYCH KONGRESACH, SYMPOZJACH, SESJACH I SPOTKANIACH
}

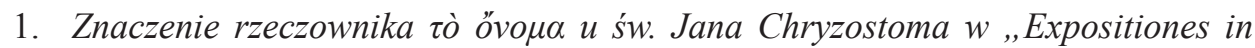
Psalmos" - posiedzenie naukowe Wydziału Historyczno-Filologicznego TN KUL, Lublin 9 III 1977.

2. Św. Jan Chryzostom jako propagator lektury Pisma Świętego - sympozjum patrystyczno-archeologiczne, Lublin 11 III 1981.

3. Ziemia Święta - kraj Biblii - Klub Inteligencji Katolickiej, Lublin 4 V 1981.

4. The Correspondence of Saint Augustine with Volusian - Catholic University of America, Washington 2 IV 1982.

5. The Bible today - Polish Catholic Intellectuals Assoc., Washington 27 VI 1982.

6. Starożytna rodzina grecka i rzymska - sympozjum patrystyczne poświęcone rodzinie w Kościele starożytnym, Lublin 24 XI 1983.

7. Kultura klasyczna u św. Augustyna - doroczna sesja Sekcji Filologicznej przy Komisji Episkopatu do spraw Nauki Katolickiej, Lublin 25 IX 1984.

8. Stosunek św. Augustyna do państwa rzymskiego w świetle jego korespondencjisympozjum patrystyczne, Lublin 21 III 1985.

9. Dialog św. Augustyna z Dioskorem - posiedzenie Polskiego Towarzystwa Filologicznego Oddziału Lubelskiego, Lublin 12 V 1985.

10. Idea pokoju i miłości ojczyzny w listach św. Augustyna - posiedzenie Polskiego Towarzystwa Filologicznego Oddziału Lubelskiego, Lublin 15 V 1986.

11. Literacki list św. Augustyna (Ep. 118, 1.1-7) - doroczna sesja Sekcji Filologicznej przy Komisji Episkopatu do spraw Nauki Katolickiej, Białystok 10 IX 1986.

12. W 1600. rocznicę nawrócenia św. Augustyna - Klub Inteligencji Katolickiej, Lublin 27 X 1986.

13. Liturgia i teologia chrztu św. Augustyna w Mediolanie - patrystyczne sympozjum naukowe zorganizowane przez Międzywydziałowy Zakład Badań nad Antykiem Chrześcijańskim KUL, Lublin 24 IV 1987.

14. Św. Augustyn - duszpasterz - wykład inauguracyjny wygłoszony w Wyższym Seminarium Duchownym, Pelplin 20 X 1987.

15. Patrystyczne inspiracje w encyklice Jana Pawła II ,,Redemptoris Mater” - okolicznościowy referat w Domu Księży Marianów, Lublin 15 III 1988.

16. Celibat kapłanów wczoraj $i$ dziś - konferencja rektorów wyższych seminariów duchownych diecezjalnych i zakonnych w Polsce, Łódź 6 IX 1988.

17. Maryja a tajemnica Kościoła u św. Augustyna - doroczne spotkanie Sekcji Patrystycznej przy Komisji Episkopatu do spraw Nauki Katolickiej, Nysa 13 IX 1988. 
18. Osobowość dobrego katechety w ujęciu św. Augustyna-patrystyczne sympozjum naukowe zorganizowane przez Międzywydziałowy Zakład Badań nad Antykiem Chrześcijańskim KUL na temat: Katecheza patrystyczna. W 1600. rocznicéśmierci św. Cyryla Jerozolimskiego, Lublin 18 X 1988.

19. Die heidnische Religion um die Wende des 4/5 Jahrhunderts im Lichte der Briefe des heiligen Augustinus - conference: Paganism in the Later Roman Empire and in Byzantium, held under the auspices of Minister of Culture and Arts of Poland, Mogilany 16-18 XI 1988.

20. Civitas Dei $i$ civitas terrena w nauczaniu Świętego Augustyna, Toruński Klub Katolików, Toruń 1988.

21. Św. Augustyn jako nauczyciel $i$ wychowawca - posiedzenie Polskiego Towarzystwa Filologicznego Oddziału Lubelskiego, Lublin 10 IV 1989.

22. Pedagogika wczesnochrześcijańska - Wyższa Szkoła Pedagogiczna, Bydgoszcz 12 IV 1989.

23. Nauczanie $i$ wychowanie $w$ teorii i praktyce św. Augustyna - VI Kongres Teologów Polskich, Lublin 12 IX 1989.

24. Znajomość św. Augustyna w Kościele Wschodnim - VI Kongres Teologów Polskich, Lublin 13 IX 1989.

25. Idea pokoju $w$ pismach św. Augustyna - Klub Inteligencji Katolickiej, Toruń 26 XI 1989.

26. Lo studio di S. Agostino in Polonia - Istituto Universitario Pareggiato di Magistero „Maria SS Assunta”, Roma 7 II 1991.

27. Gli studi patristici in Polonia - Istituto Universitario Pareggiato di Magistero „Maria SS Assunta”, Roma 8 II 1991.

28. Troska o dobro ojczyzny $w$ teorii i praktyce św. Augustyna - sympozjum patrystyczne w Akademii Teologii Katolickiej, Warszawa 28 II 1991.

29. Dziecko w Biblii - konferencja naukowa zorganizowana przez Katedrę Historii Wychowania Wyższej Szkoły Pedagogicznej, Bydgoszcz 20 V 1991.

30. Percepcja św. Augustyna w Kościele Wschodnim - posiedzenie Polskiego Towarzystwa Filologicznego Oddziału Lubelskiego, Lublin 24 VI 1991.

31. Teologia kapłaństwa w pismach św. Augustyna - patrystyczne sympozjum naukowe zorganizowane przez Międzywydziałowy Zakład Badań nad Antykiem Chrześcijańskim KUL, Lublin 30 X 1991.

32. Nauka św. Augustyna o pokorze jako podstawie ascezy chrześcijańskiej-doroczne spotkanie Sekcji Patrystycznej przy Komisji Episkopatu do spraw Nauki Katolickiej, Paradyż 23 IX 1992.

33. Troska o ubogich $w$ nauczaniu $i$ działalności św. Augustyna - patrystyczne sympozjum naukowe zorganizowane przez Międzywydziałowy Zakład Badań nad Antykiem Chrześcijańskim KUL poświęcone pracy charytatywnej w starożytności chrześcijańskiej, Lublin 28 X 1992.

34. „Humanitas” w pismach św. Augustyna - posiedzenie Polskiego Towarzystwa Filologicznego Oddziału Lubelskiego, Lublin 21 XII 1992.

35. Język i styl św. Augustyna - doroczna sesja Sekcji Filologicznej przy Komisji Episkopatu do spraw Nauki Katolickiej, Olsztyn 15 IX 1993. 
36. Matżeństwo i rodzina w starożytności chrześcijańskiej-duszpasterskie spotkanie księży, Pelplin 2 XII 1993.

37. Rodzina w starożytności - posiedzenie naukowe Wydziału Historyczno-Filologicznego TN KUL, Lublin 13 I 1994.

38. Starożytne chrześcijaństwo a problemy ekumeniczne - wykład okolicznościowy dla księży, Pelplin 24 I 1994.

39. Koncepcja pokoju i wojny w nauczaniu Ojców Kościoła - VIII Bydgoskie Dni Społeczne, Bydgoszcz 17 III 1994.

40. Rodzina chrześcijańska w starożytności - doroczna sesja Sekcji Filologicznej przy Komisji Episkopatu do spraw Nauki Katolickiej, Ołtarzew 12 IX 1994.

41. Obraz rodziny św. Augustyna - doroczna sesja Sekcji Filologicznej przy Komisji Episkopatu do spraw Nauki Katolickiej, Ołtarzew 12 IX 1994.

42. Recepcja pisarzy wczesnochrześcijańskich $w$ Polsce w perspektywie historycznej - sesja naukowa poświęcona kulturze antycznej w Europie Środkowej i Wschodniej, Lwów 3 X 1994.

43. Koncepcja przyjaźni w dziełach św. Augustyna - doroczna sesja Sekcji Filologicznej przy Komisji Episkopatu do spraw Nauki Katolickiej, Radom 12 IX 1995.

44. Chrześcijańska przyjaźń w ujęciu św. Augustyna - doroczne spotkanie Sekcji Patrystycznej przy Komisji Episkopatu do spraw Nauki Katolickiej, Gniezno 26 IX 1995.

45. Rozwój pojęcia ,, amicitia” w pismach św. Augustyna - posiedzenie Polskiego Towarzystwa Filologicznego Oddziału Lubelskiego, Lublin 26 X 1995.

46. Czystość kapłańska w nauce Ojców Kościoła - spotkanie z franciszkanami, Kraków 12 XII 1995.

47. Ojcowie Kościoła o kapłaństwie - Instytut Dokształcania Sakramentalnego, Pelplin 5 II 1996.

48. Maryja w tajemnicy Kościoła - posiedzenie naukowe Komisji Badań nad Antykiem Chrześcijańskim TN KUL, Lublin 29 II 1996.

49. W stużbie Ewangelii - spotkanie Instytutów Życia Konsekrowanego, Nałęczów 3 V 1996.

50. Sztuka wymowy wedtug św. Augustyna - doroczna sesja Sekcji Filologicznej przy Komisji Episkopatu do spraw Nauki Katolickiej, Kielce 10 IX 1996.

51. Historia $w$ świetle pism św. Augustyna - Walne Zgromadzenie Polskiego Towarzystwa Filologicznego, Kamień Śląski 20 IX 1996.

52. Ojcowie ponicejscy wobec kultury klasycznej - doroczne spotkanie Sekcji Patrystycznej przy Komisji Episkopatu do spraw Nauki Katolickiej, Toruń 23 IX 1996.

53. Św. Augustyn jako komentator Symbolu Apostolskiego - sympozjum interdyscyplinarne poświęcone Symbolowi Apostolskiemu w nauce i sztuce Kościoła pierwszego tysiąclecia, Lublin 24 XI 1996.

54. Dobroć i piękno ludzkiego ciała w pismach świętego Augustyna - konferencja naukowa zorganizowana przez Instytut Filologii Klasycznej i Kultury Antycznej Uniwersytetu Wrocławskiego na temat: Starożytni Grecy i Rzymianie wobec otaczającego świata, Wrocław 13-14 XII 1996. 
55. Pisarze wczesnochrześcijańscy wobec kultury klasycznej - doroczna sesja Sekcji Filologicznej przy Komisji Episkopatu do spraw Nauki Katolickiej, Przemyśl 12 IX 1997.

56. Grzech pierworodny jako źródło cierpień człowieka u św. Augustyna - doroczne spotkanie Sekcji Patrystycznej przy Komisji Episkopatu do spraw Nauki Katolickiej, Kraków 19 IX 1997.

57. Święty Ambroży w pismach św. Augustyna - Międzynarodowe Sympozjum Ambrozjańskie w KUL, Lublin 26 XI 1997.

58. Wierzę w Ducha Świętego - Jasnogórski Wieczernik dla Instytutów Świeckich, Częstochowa 16 V 1998.

59. Wielkość i godność kobiety według świętego Augustyna - Sympozjum Patrystyczne Akademii Teologii Katolickiej poświęcone kobiecie w starożytności chrześcijańskiej, Warszawa 22 X 1998.

60. Polskie badania nad św. Augustynem - sympozjum naukowe Polskie studia nad antykiem chrześcijańskim z okazji 30-lecia działalności Międzywydziałowego Zakładu Badań nad Antykiem Chrześcijańskim, Lublin 26 V 1999.

61. „Incarnatio Christi” w pismach świętego Augustyna - Sympozjum Instytutu Filologii Klasycznej i Wydziału Historyczno-Filologicznego Towarzystwa Naukowego KUL z okazji 20. rocznicy śmierci śp. prof. Leokadii Małunowiczówny, Lublin 10 V 2000.

62. Wcielenie Chrystusa w nauczaniu świętego Augustyna - Doroczna Sesja Sekcji Filologicznej przy Komisji Episkopatu do spraw Nauki Katolickiej, Koszalin 13 IX 2000.

63. Koncepcja czasu w ujęciu świętego Augustyna - Jubileuszowe Spotkanie Sekcji Patrystycznej przy Komisji Episkopatu do spraw Nauki Katolickiej, Ełk 21 IX 2000.

64. Święty Augustyn o matżeństwie i dziewictwie - posiedzenie naukowo-administracyjne Wydziału Historyczno-Filologicznego Towarzystwa Naukowego KUL, Lublin 5 X 2000.

65. Wcielenie Stowa w nauczaniu świętego Augustyna - sympozjum naukowe Międzywydziałowego Zakładu Badań nad Antykiem Chrześcijańskim KUL, Lublin 27 XI 2000.

66. Kapłan a kobieta - sympozjum dla kapłanów poświęcone tematowi: „Moca Ducha Świętego" - powołani do świętości, Częstochowa 31 I 2002.

67. Saint' Agostino in Polonia - XII Tydzień Augustyński w Cassago Brianza, 8 IX 2002.

68. Problem dzieci nieochrzczonych według świętego Augustyna - doroczne spotkanie Sekcji Patrystycznej przy Komisji Nauki Wiary Episkopatu Polski, Kielce 23-24 IX 2002.

69. Aktualność świętego Augustyna - referat wygłoszony podczas sesji naukowej na temat: Święty Augustyn i jego ,,Wyznania”, z udziałem profesorów KUL i Uniwersytetu we Fryburgu (Szwajcaria), Lublin 21 X 2002.

70. Przebóstwienie człowieka w świetle pism wczesnochrześcijańskich - referat wygłoszony w czasie sympozjum zorganizowanego przez Katedrę Filozofii Religii 
KUL na temat: Filozofować w kontekście teologii. Religia - natura - łaska, Lublin 26 X 2002.

71. „Sacerdotium regale” w nauce św. Augustyna - sympozjum w KUL o roli świeckich w Kościele Starożytnym, 26 XI 2002.

72. Święty Augustyn wobec religii niechrześcijańskiej - sympozjum z cyklu Filozofowanie w kontekście teologii, Katedra Filozofii Religii KUL, Lublin 24 IV 2003.

73. Kult męczenników w świetle pism św. Augustyna - IV sympozjum Kazimierskie: Męczennicy w świecie późnego antyku, Kazimierz Dolny 5 V 2003.

74. The Deification of Man in Saint Ambrose's Writings - Międzynarodowy Kongres o Neoplatonizmie: Byt czy dobro - metamorfozy neoplatonizmu, Lublin 7-10 X 2003.

75. Święty Augustyn dla Europy - VII Kongres Teologów Polskich, Lublin 12-15 IX 2004.

76. Biskup Rzymu w pismach świętego Augustyna - sympozjum patrystyczne: Papiestwo w starożytności chrześcijańskiej, Lublin 23-24 XI 2004.

77. Augustyńskie Credo - Colloquium Augustinianum: Św. Augustyn dzisiaj, Kraków 2-3 XII 2004.

78. Teoria sztuki w pismach św. Augustyna - posiedzenie Towarzystwa Naukowego Wydziału Historyczno-Filologicznego KUL, Lublin 27 IX 2006.

79. Teoria sztuki w pismach św. Augustyna - posiedzenie Polskiego Towarzystwa Filologicznego Oddziału Lubelskiego, Lublin X 2006.

80. Jan Paweł II a 1600. rocznica nawrócenia świętego Augustyna - Międzynarodowe Sympozjum Patrystyczne: Jan Pawet II a Antyk Chrześcijański, Instytut Badań nad Antykiem Chrześcijańskim KUL, Lublin 28-29 XI 2006.

81. Bogactwo i ubóstwo w pismach św. Augustyna - sympozjum historyczne zorganizowane przez Kieleckie Towarzystwo Naukowe, Kielce 2009.

82. Święty Augustyn o greckich autorach - Jubileuszowa Konferencja Naukowa zorganizowana przez Instytut Filologii Klasycznej KUL, Lublin 9 X 2009.

83. Dziewice $i$ wdowy w literaturze wczesnochrześcijańskiej-sympozjum poświęcone formom życia konsekrowanego zorganizowany przez Instytuty Życia Konsekrowanego, Pelplin 17 X 2009.

84. Fundamenty cywilizacji europejskiej: Antyk w kulturze - Dzień Kulturoznawcy: Kultura i dyplomacja kulturalna zorganizowany przez Instytut Kulturoznawstwa KUL, Lublin 13 I 2010.

85. Udziat św. Augustyna w tworzeniu kultury Europy - posiedzenie naukowe Komisji Badań nad Antykiem Chrześcijańskim KUL, Lublin 15 IV 2010.

86. Obraz ludzi starszych w pismach św. Augustyna - Międzynarodowe Sympozjum Patrystyczne: Stosunek do ludzi starszych w starożytności klasycznej i chrześcijańskiej, Ośrodek Badań nad Antykiem Chrześcijańskim KUL, Lublin 25-26 XI 2010.

87. Teoria sztuki w nauczaniu Świętego Augustyna - posiedzenie naukowe Komisji Badań nad Antykiem Chrześcijańskim KUL, Lublin 19 V 2011.

88. Radość w pismach św. Augustyna - sympozjum patrystyczne na temat: Radość u Ojców Kościoła ku czci ks. Franciszka Drączkowskiego, Lublin 4 X 2011.

89. Zstapił do piekiet $w$ nauczaniu Świętego Augustyna - posiedzenie naukowe Komisji Badań nad Antykiem Chrześcijańskim KUL, Lublin 15 III 2012. 
90. Sztuki klasyczne w chrześcijańskim wychowaniu wedtug Świętego Augustyna Konferencja Międzynarodowa: Paideia sive institutio moralis et civilis omnium terrarium civium zorganizowana przez Instytut Filologii Klasycznej, Lublin 15 V 2012.

91. „Narodził się z Maryi Dziewicy” w interpretacji Ojców Kościoła - posiedzenie Komisji Badań nad Antykiem Chrześcijańskim KUL, Lublin 17 I 2013.

92. „Sapientia” w ,Sermones” $i$,,Enarrationes in Psalmos ” św. Augustyna-posiedzenie Komisji Badań nad Antykiem Chrześcijańskim KUL, Lublin 18 IV 2013.

93. „Credo” u Świętego Augustyna. Aspekt filologiczny - doroczne spotkanie Sekcji Patrystycznej przy Komisji Episkopatu do spraw Nauki Katolickiej, Toruń 23 IX 2013.

94. Nawrócenie Świętego Augustyna - posiedzenie Polskiego Towarzystwa Naukowego Oddziału Lubelskiego, Lublin 29 X 2013.

95. Monika z Tagasty - humanistka i święta - posiedzenie Wydziału Historyczno-Filologicznego Towarzystwa Naukowego KUL, Lublin 10 I 2014.

Zebrała Anna Maćkowska, Lublin, KUL 